\title{
STUDIES ON THE WHITE-CLAWED CRAYFISH (AUSTROPOTAMOBIUS PALLIPES) ASSOCIATED WITH MUDDY HABITATS
}

D. M. HOLDICH (1), S. PEAY (2), J. FOSTER (3), P.D. HILEY (2), J. H. BRICKLAND (4)

(1) EMEC Ecology, The Old Ragged School, Brook Street, Nottingham, NG1 1EA, UK. E-Mail: david.holdich@ntlworld.com

(2) Scott Wilson, The Design Innovation Centre, 46 The Calls, Leeds, LS2 7EY, UK.

(3) Environment Agency, Saxon House, Little High Street, Worthing, West Sussex BN11 1DH, UK.

(4) British Waterways, Fearns Wharf, Neptune Street, Leeds, LS9 8PB, UK.

Reçu le 16 juin 2005

Accepté le 15 novembre 2005
Received June 16, 2005 Accepted November 15, 2005

\begin{abstract}
The white-clawed crayfish, Austropotamobius pallipes, is usually found associated with stony habitats containing obvious refuges in the form of gaps between and under rocks, macrophytes and marginal tree roots, particularly in streams and lakes with clear water and little marginal mud. If the banks are composed of suitable material, then they may also construct and live in burrows. However, the white-clawed crayfish is also found to be abundant in streams, rivers, canals and millraces with deep, anoxic mud and with very little aquatic vegetation. Foraging on the surface of mud may be the only way they can obtain sufficient food in the form of macroinvertebrates and decaying plant matter. Where do crayfish live in this restricted habitat? Dewatering such waterways for essential engineering works, such as desilting, bridge and weir repairs, bank reinforcements, and maintenance of outfalls can provide an excellent opportunity to study the available habitat and the crayfish populations, in addition good estimates of population size and age class distribution can be obtained, although, as with other methods, juveniles tend to be underrepresented. A number of case studies will be given to illustrate the fact that white-clawed crayfish are able to colonize muddy habitats in some numbers. The value of retaining trees with their roots hanging into waterways as a refuge for both crayfish and small fish is highlighted.
\end{abstract}

Key-words: white-clawed crayfish, size classes, mud, dewatering, surveys.

\section{ÉTUDES SUR L'ÉCREVISSE À PATTES BLANCHES (AUSTROPOTAMOBIUS PALLIPES) DANS LES HABITATS VASEUX}

\section{RÉSUMÉ}

L'écrevisse à pattes blanches, Austropotamobius pallipes, se trouve généralement dans des habitats pierreux qui offrent des refuges faciles dans les interstices entre et sous les rochers, les macrophytes, les racines d'arbres et les radicelles. On les retrouve particulièrement dans des ruisseaux et des lacs à eau claire, où il y a peu de vase et de 
limon. Si les berges le permettent, les écrevisses peuvent construire et vivre dans des terriers. Cependant, l'écrevisse à pattes blanches est aussi présente dans des ruisseaux, rivières, canaux et biefs d'amont profonds, vaseux et anoxiques, avec très peu de végétation aquatique. Fouiller à la surface de la vase peut être la seule façon pour elles d'obtenir leur nourriture, sous forme de macro invertébrés et plantes en décomposition. Où vivent les écrevisses dans cet habitat restreint ? L'assèchement de ces cours d'eau (vidange) pour des travaux de voirie ainsi que le creusement pour les réparations de ponts ou de barrages, le renforcement de berges et le maintien du débit peuvent fournir une excellente opportunité d'étudier les habitats disponibles et les populations d'écrevisses. De plus, une bonne estimation de la taille de la population et de la pyramide des âges peut être ainsi obtenue, tandis que, comme avec les autres méthodes, les juvéniles ont tendance à être sous-représentés. Un nombre d'études de cas seront présentés pour illustrer le fait qu'un certain nombre d'écrevisses à pattes blanches sont capables de coloniser des habitats vaseux. Ceci souligne l'importance de préserver les arbres sur les berges pour que les racines et radicelles deviennent un refuge pour à la fois les écrevisses et les petits poissons.

Mots-clés : écrevisse à pattes blanches, classes de taille, vaseux, vidange.

\section{INTRODUCTION}

A common perception is that white-clawed crayfish, Austropotamobius pallipes (LEREBOULLET), live in clean, well-oxygenated, calcium-rich water that does not contain too much sediment, and that they tend to be found in rivers and lakes with plenty of refuges in the form of large stones, submerged logs, debris and tree roots; with or without marginal vegetation (HOLDICH and ROGERS, 2000; GRANDJEAN et al., 2003; HOLDICH, 2003). If the substrate is suitable then they may also burrow into banks (PEAY and HIRST, 2003; TERO et al., 2003), which gives them added protection from predation and from spate conditions after heavy rain. However, some recent studies in the UK have shown that the white-clawed crayfish can also be found in locations with deep, anoxic sediment (mud), with no aquatic macrophytes or algae, and little if any marginal vegetation. The quality of the water may be good, but the habitat quality is not what would be expected for the white-clawed crayfish. No mention is made of white-clawed crayfish occupying muddy habitats in SMITH et al. (1996) or NAURA and ROBINSON (1998), who have surveyed habitat features suitable for white-clawed crayfish. Deep deposits of mud can accumulate behind weirs, in canals, over-deepened rivers and other slow-flowing waters or by decay of aquatic vegetation in still waterbodies.

The turbidity of water during surveys of muddy habitats can make it difficult to detect the presence of crayfish populations and any surveys tend to be carried out by trapping, the method with the greatest size bias (BROWN and BREWIS, 1979). However, on occasions it is necessary to remove the mud from waterways to prevent flooding or maintain navigation. Desilting can be done by dredging when the water is present or after dewatering. Dewatering may also be necessary for essential engineering works on bridges, weirs re-inforced banks or outfalls (LOWERY and HOGGER, 1986; PEAY, 2000; BRICKLAND et al., 2006). In England and Wales, when the regulatory authority advises project engineers that white-clawed crayfish may be present in a waterbody, there is a requirement for crayfish surveys and mitigation measures, because the white-clawed crayfish is a protected species in the UK (PEAY, 2000; HOLDICH et al., 2004).

During dewatering white-clawed crayfish tend to respond to exposure to air by leaving their refuges in search of submerged alternatives, which makes them visible (PEAY, 2000). In principle this should provide a better representation of the whole population than conventional survey methods. Electrofishing, trapping, night viewing, and manual 
searches all underestimate the smaller age classes to varying degrees (PEAY, 2004), although a combination of methods can reveal a good spread of age classes (DEMERS and REYNOLDS, 2002). In a normal population of astacid crayfish one would expect juveniles to represent the highest number, followed by a gradual decline in numbers over the age classes, ending with just a few old individuals (Type III survivorship curve). This is not what is shown by most studies, which usually show a bell-shaped graph, the highest number being represented by individuals probably 2-5 years old. The degree to which this bell curve is displaced away from the Type III curve towards the large sizes indicates the degree of size selectivity of the method employed (PEAY, 2004).

This paper presents a number of case studies from England, involving various types of waterway that have been temporarily dewatered, or desilted with the water in place (River Derwent). None of these studies has been carried out with the specific purpose of investigating crayfish populations, but instead opportunities have been taken to collect data on habitats and populations immediately before and during the engineering operations. During such work, crayfish surveys and rescues are carried out by statutory agencies, or ecological consultants who work for the agencies or developers. Such projects are constrained by budgets, project programmes, the work of the contractors on site and sometimes by physical constraints on safe working. Although short project reports are written, such work is rarely prepared for publication and any findings may go largely ignored. Post-project monitoring is not mandatory and is not often done (PEAY, 2003), although there are exceptions (PEAY et al., 2006).

The case studies described below were carried out in different circumstances, some of which are not ideal for scientific study. They all had crayfish occupying habitats associated with or on deep mud to varying degrees. The term "mud" is used loosely, as no constituent analyses were undertaken, although some descriptions are given. Some of the muds have a greater or lesser content of clay or sand, but all of them have a proportion of organic silt, which may be brown and oxidised at the surface in contact with well-aerated water, but is black and anoxic below the surface. When disturbed, deep areas of anoxic mud may release bubbles of hydrogen sulphide. The consistency varies at the different sites, as evidenced by the depth to which a crayfish surveyor will sink. The authors suggest that such mud may be less of a barrier to the movement of white-clawed crayfish than previously thought.

Comments are made about the life style of crayfish living in such muddy habitats, whether their population structure can be determined more accurately by hand collecting after dewatering than by more standard methods, and whether the populations showed signs of stress by living in such restricted habitats.

\section{CASE STUDIES}

\section{General}

In the graphs given for each site, carapace length $(C L)$ is given in $5 \mathrm{~mm}$ categories from 4.0-8.9 to 54.0-58.9 for comparative purposes. All crayfish work was undertaken with appropriate licences from English Nature and the Environment Agency.

\section{River Derwent (S. PEAY AND P.D. HILEY)}

\section{Site description}

The River Derwent in North Yorkshire (northern England) has limestone underlying its moorland headwater streams, but near the village of West Ayton (UK Ordnance Survey grid reference: SE 990 854), as it approaches the floodplain, the river is partially regulated by old mill weirs. A reach upstream of the weirs used to be dredged annually until 1989. By 
1998 dredging of approximately $800 \mathrm{~m}$ of the river was required, together with works on the intake control of an abstraction for public water supply. The whole river is designated as a Site of Special Scientific Interest for features including its population of white-clawed crayfish.

The land adjacent to the river is pasture, with occasional alder trees (Alnus glutinosa) on the banks, broadleaved woodland and gardens. Prior to the works, the channel was about $10 \mathrm{~m}$ wide and very slow-flowing. The margins of the previously trapezoidal channel had filled with mud to less than $0.5 \mathrm{~m}$ deep and part of this had developed a dense fringe of emergent vegetation, mainly common reed, Phragmites australis, and reed sweet-grass, Glyceria fluitans. As the silt reduced the depth, the river scoured a mid-channel about $2 \mathrm{~m}$ wide and up to $1 \mathrm{~m}$ deep, down to the underlying limestone gravel.

\section{Methods}

A preliminary survey was carried out to find out whether crayfish were present in what appeared to be relatively unfavourable habitat. A total of $900 \mathrm{~m}$ of river was subdivided into $50 \mathrm{~m}$ sections, which were surveyed in dry weather conditions on two nights in August 1998. Only three of the sections were surveyed on both nights. Surveyors in dry suits moved upstream along the mid channel, viewing the gravel bottom and submerged mud by torchlight and catching crayfish by hand. Access to the channel was limited in a few sections due to deep, soft mud.

The dredging of $800 \mathrm{~m}$ of river was done with a $360^{\circ}$ slew excavator. Mud and plants were deposited on the bank and checked manually for crayfish. Some marginal vegetation and all the roots of trees were left undisturbed in the channel. Dredging was carried out very slowly, taking a total of 12 days during a 3-week period in August to September. An average of $66 \mathrm{~m}$ channel was dredged each day.

All crayfish recovered were sexed, and their carapace length (CL) measured in $\mathrm{mm}$. Rescued crayfish were relocated to a site upstream. Abundant artificial refuges were provided and fish scraps were offered. The crayfish were not confined and gradually dispersed.

\section{Results}

In all, 70 crayfish were recorded in a $900 \mathrm{~m}$ length, an average of 3.8 per $50 \mathrm{~m}$ subsection (range 0 to 11). Of these, 53 crayfish were captured and removed and the other 17 escaped. In some sections the central part of the channel was flanked by steep, submerged mud banks in which there were several small burrows per square metre on both sides of the mid-channel. Their occupancy by white-clawed crayfish was evident by projecting chelae, antennae and by the characteristic red eye-shine. Where burrows were seen along these submerged banks the abundance was in the order of 1-25 $\mathrm{m}^{-2}$. Crayfish were also seen sitting and walking on the surface of bare, submerged mud on the flat areas between the incised mid channel and the edge of the reed swamp.

The median size of crayfish from night viewing (Figure 1) was $36 \mathrm{~mm} \mathrm{CL}$, with only adults of $22 \mathrm{~mm} \mathrm{CL}$ and above seen during the surveys. Half the crayfish caught were female and both male and female had the same median size class (class 7: 34.0-38.9 mm), although the distribution of males extended to larger size classes than females (maximum size of females $45 \mathrm{~mm} \mathrm{CL}$ and males $51 \mathrm{~mm}$ ). No berried females were collected, as the breeding season had not commenced.

In all, 1032 crayfish were recovered from the dredging of $800 \mathrm{~m}$ of river. The average number of crayfish recovered after dredging was 64 per $50 \mathrm{~m}$ section, but there was considerable variation, ranging from 11 to 215 per section. Only aggregated counts were available for chainages $100-250 \mathrm{~m}$ and $550-650 \mathrm{~m}$ respectively. There was no correlation 


\section{Table I}

Carapace length categories $(\mathrm{mm})$.

Tableau I

Classes de longueur de carapace $(\mathrm{mm})$.

\begin{tabular}{c|c}
\hline Size category & Carapace length $(\mathbf{m m})$ \\
\hline 1 & $4.0-8.9$ \\
2 & $9.0-13.9$ \\
3 & $14.0-18.9$ \\
4 & $19.0-23.9$ \\
5 & $24.0-28.9$ \\
6 & $29.0-33.9$ \\
7 & $34.0-38.9$ \\
8 & $39.0-43.9$ \\
9 & $44.0-48.9$ \\
10 & $49.0-53.9$ \\
11 & $54.0-58.9$ \\
\hline
\end{tabular}

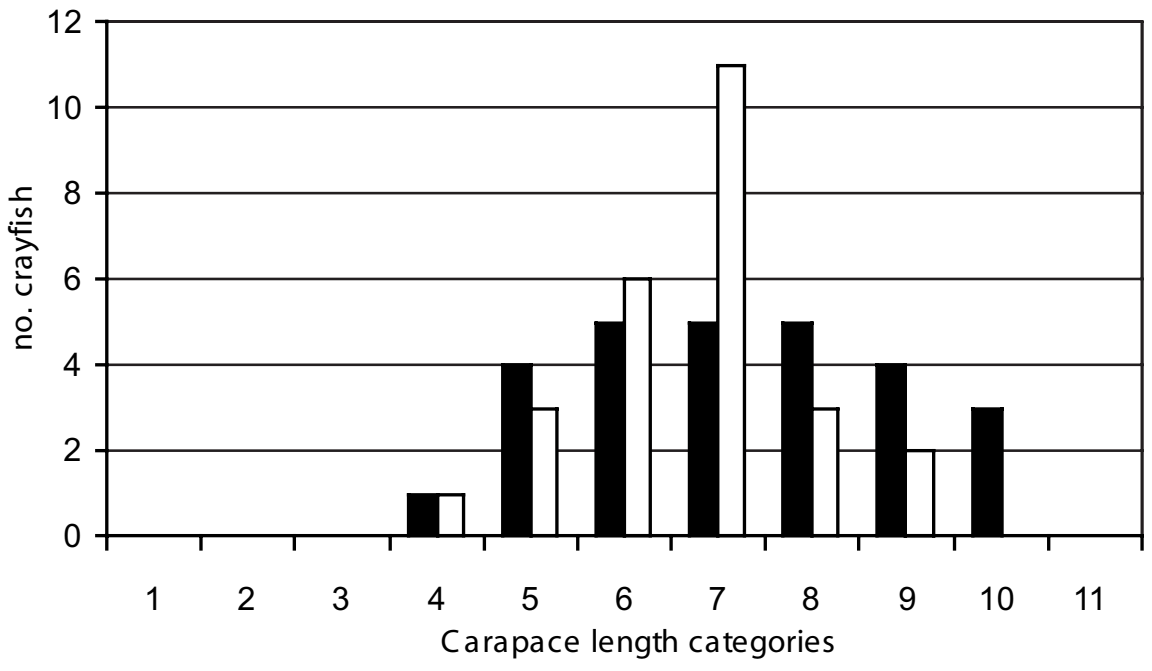

Figure 1

River Derwent at West Ayton. Size distribution of males (black) and females (white) collected during night viewing.

\section{Figure 1}

Rivière Derwent Ayton ouest. Distribution en taille des mâles (noir) et des femelles (blanc) récoltés pendant l'échantillonnage de nuit.

evident between the number of crayfish recorded during night viewing and the number retrieved from dredged material (Figure 3). The size distribution (Figure 2) for dredged crayfish shows an approximately symmetrical distribution about the overall median size of 30 mm CL (class 5: 24.0-28.9 mm CL, males; class 6: 29.0-33.9 mm CL, females). 


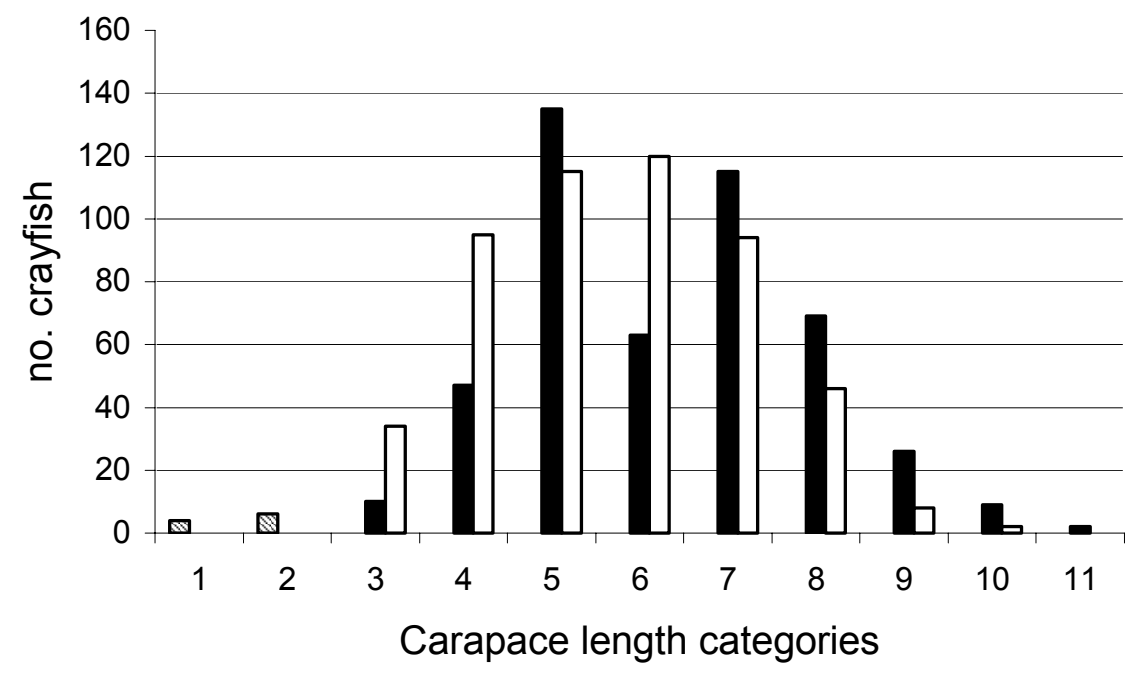

Figure 2

River Derwent at West Ayton. Size distribution of juveniles (diagonal stripes), males (black) and females (white) collected from dredged material.

\section{Figure 2}

Rivière Derwent Ayton ouest. Distribution en taille des juvéniles (rayures diagonales), des mâles (noir) et des femelles (blanc) récoltés dans la vase draguée.

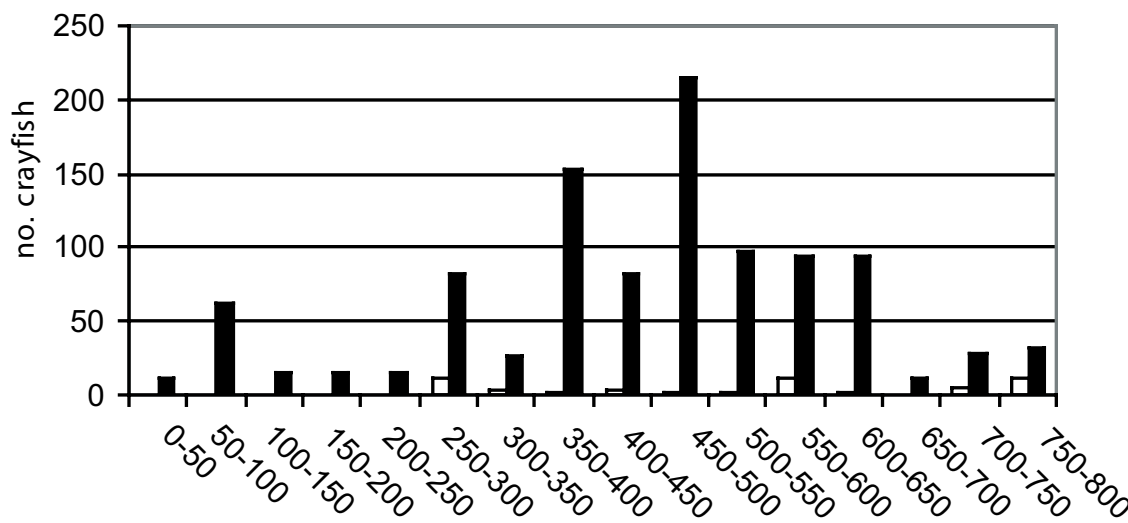

Chainage upstream of weir, $m$

$\square$ night-viewing $\boldsymbol{\square}$ dredged

Figure 3

River Derwent at West Ayton. Crayfish recorded by night-viewing.

\section{Figure 3}

Rivière Derwent Ayton ouest. Écrevisses observées pendant l'échantillonnage de nuit. 


\section{Discussion}

The catch from night-viewing represented only $4 \%$ of the total catch by dredging. Juveniles and sub-adults below $19 \mathrm{~mm} \mathrm{CL}$ in particular are likely to have been significantly under-recorded in both night-viewing and dredging. The crayfish below $19 \mathrm{~mm} \mathrm{CL}(n=54)$ represented only $5 \%$ of the total crayfish removed by dredging. Even dredging probably gave a large underestimate of the total population. Some crayfish dredged out of the river may have been able to swim away as the bucket was lifted, or may have remained unseen within the dredged material.

Burrow density can give some indication of the population size. Burrows were usually wider than high, with a flattened base and $10 \mathrm{~mm}$ or more in width. Reed swamp extended for 0.5 to $3.0 \mathrm{~m}$ on both sides and it was not easy to see whether any burrows were present in these gently sloping margins. Just considering the submerged slopes along the mid-channel, taking an estimate of 20 burrows per linear metre of channel (10 on each side) and half of them occupied, this would equate to a population of 8000 subadult or adult crayfish in the $800 \mathrm{~m}$ dredged. This crude assumption suggests the crayfish obtained by dredging might represent only $12 \%$ of the total in "catchable" size classes.

It was not feasible to separate crayfish dredged from reed swamp from those in bare mud. Nonetheless, many crayfish were retrieved from bucketfuls of soft black mud with little or no vegetation present.

\section{Mortimer's Cross (J. FOSTER)}

\section{Site description}

Mortimer's Cross is a naturalised $19^{\text {th }}$ century millrace connected to the River Lugg in Herefordshire, (western England) (OS grid reference: SO 426 637), which was studied by FOSTER $(1995,1996)$. The slow flowing millrace is $170 \mathrm{~m}$ long, $4 \mathrm{~m}$ wide and $1 \mathrm{~m}$ deep with a surface area of $680 \mathrm{~m}^{2}$. It has steep U-shaped clay banks embedded with alder (Alnus glutinosa) tree-roots. At the time of the study, the bed of the millrace consisted predominantly of black silt, although gravel and larger stones covered about $5 \%$ of the bed. Canadian pondweed (Elodea canadensis) and other vegetation (notably yellow flag or water iris, Iris pseudacorus, at the periphery of the millrace) covered less than $10 \%$ of the millrace. The millrace was frequented by European otters, Lutra lutra, and crayfish remains were observed in otter spraints at the site.

A narrow sluice gate with a log and litter dam at the downstream end of the millrace and a mud bank at the upstream end of the millrace (where water flowed in from the River Lugg) significantly reduced loss of aquatic animals when the millrace was drained.

An intensive survey was undertaken of the white-clawed crayfish population in late August 1989.

\section{Methods}

The millrace was drained for collection of crayfish and refilled after sampling on two consecutive days. When the millrace was drained, stranded crayfish were collected by hand on the muddy bottom of the millrace, in exposed tree-root systems and under cobbles at the periphery of the millrace, or by scraping a hand held net through a few small isolated shallow pools (maximum depth c. $10 \mathrm{~cm}$ ).

The crayfish were measured ( $\mathrm{CL}$ in $\mathrm{mm}$ ), sexed, checked for signs of disease (notably porcelain disease and burnspot disease), incidence of claw loss and regeneration and other damage, and were returned to the millrace on the two consecutive days. Crayfish sampled on the first day were marked with white correcting fluid on the carapace 
to facilitate population estimation by mark-recapture techniques. A sample of crayfish marked by this method in captivity retained the mark for several days. Population estimates were calculated from mark-recapture data using the adjusted Petersen Method (RICKER, 1975).

\section{Results}

Manual searches revealed that the crayfish were restricted to about $10 \%$ of the available area in the millrace, among favourable habitat in the alder tree-root systems, crevices in the bank, and to a lesser extent, under cobbles, giving high local densities of about $20 \mathrm{~m}^{-2}$, but more often $2.0 \mathrm{~m}^{-2}$ for $\geq 17 \mathrm{~mm} \mathrm{CL}$ individuals.

Of the 598 white-clawed crayfish collected manually, the largest female was $45 \mathrm{~mm} \mathrm{CL}$ while the largest male was $52 \mathrm{~mm} \mathrm{CL}$. The male:female ratio was 0.84 . No berried females were collected, as the breeding season had not commenced. Accurate population estimates of crayfish smaller than $17 \mathrm{~mm}$ carapace length (CL) could not be determined, but examination of the length frequency distributions indicates that there were probably fewer juvenile crayfish less than $17 \mathrm{~mm} \mathrm{CL}$ than adult crayfish greater than $17 \mathrm{~mm} \mathrm{CL}$ (Figure 4). It was estimated from the mark recapture exercise that the total population of crayfish in the millrace that were 2 + or older was 1,387 (lower 95\% confidence limit $=1,013$, upper $95 \%$ confidence limit $=1,952$ ).

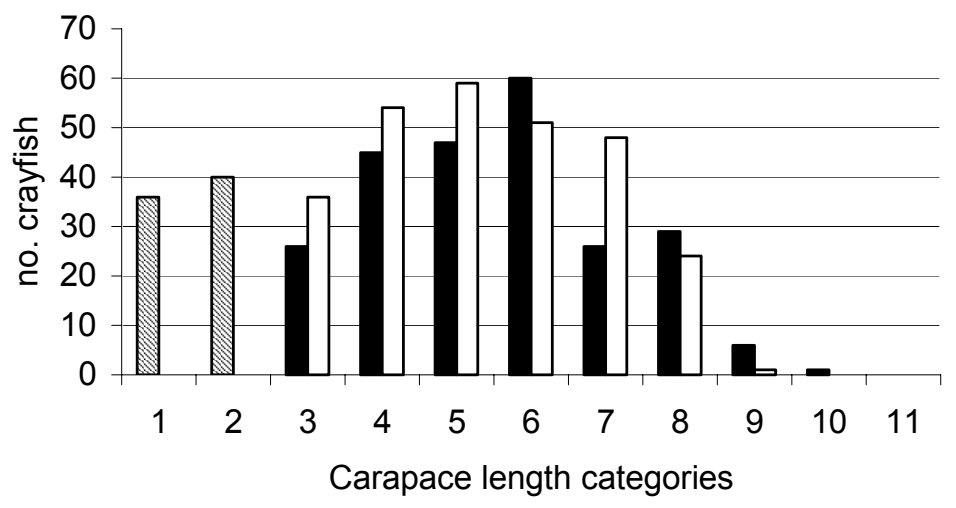

Figure 4

Mortimer's Cross. Size distribution of juveniles (grey), males (black) and females (white) collected by hand after drain down of millrace.

\section{Figure 4}

Mortimer's Cross. Distribution en taille des juvéniles (gris), des mâles (noir) et des femelles (blanc) récoltés à la main après la vidange de l'étendue d'eau en aval du moulin.

The incidence of porcelain disease, Thelohania contejeani, was $10.4 \%$, but that in males $(13.4 \%)$ was nearly twice that in females $(7.5 \%)$. Burnspot disease only afflicted $0.8 \%$ of the population. Claw loss or regeneration affected a substantial $27 \%$ of the population.

\section{Discussion}

The mean population densities of crayfish of $\geq 17 \mathrm{~mm} \mathrm{CL}$ in the millrace of $2.0 \mathrm{~m}^{-2}$, with localised densities of about $20 \mathrm{~m}^{-2}$ in favourable habitat, are comparable with estimates of white-clawed crayfish and other astacid species in lentic environments (HOGGER, 1988). 
It has been suggested that, as in this study, high densities of white-clawed crayfish are found in areas of more favourable habitat and low densities are found in areas of less favourable habitat. In this study, no crayfish were found on the mud/silt substrates in the daytime that represented over $90 \%$ of the in-channel habitat, but moderate densities were recorded under cobbles and high densities were recorded in alder tree-root systems. Leaf litter accumulated beneath the tree root systems and it is likely that this and its associated aquatic invertebrates were a source of food for the crayfish. However, the study was only undertaken in the daytime and it may be that the crayfish respond to diurnal rhythms and utilise the muddy substrate at night by moving about it and feeding on aquatic invertebrates typical of muddy substrates, such as oligochaetes and chironomids. They are less likely to be predated on the refuge poor muddy substrate at night than in the daytime. If this is the case, it implies that refuge-poor muddy habitats can still be of importance as a food resource for white-clawed crayfish.

\section{Markeaton Brook (D.M. HOLDICH)}

\section{Site description}

Markeaton Brook in Derbyshire (central England) flows through an intensively farmed floodplain of alluvial mud over gravel (B. RHODES, 2005, pers. comm.). It has been dammed near the source by weirs to form a series of on-line lakes, which are relatively shallow and silted. White-clawed crayfish are common, particularly around the weirs where there are tree roots and some rocks. Numerous crayfish (1100) were rescued when an area was dewatered in 2000 for repairs on a weir, although no measurements were made. A manual search prior to dewatering only revealed 20 crayfish at the same site. Previous surveys had confirmed that the stream had good biological water quality and that white-clawed crayfish were present at other sites, including Markeaton Park, about $2 \mathrm{~km}$ downstream of the lakes.

At Markeaton Park, (OS grid reference: SK 333 378) the brook flows under a bridge into an on-line stilling pond, which traps the silt (Site A, 10-25 m wide, with a left bank length of $185 \mathrm{~m}$ ). The pond overflows via two weirs, one into a spillway, and the other into a culvert that leads into another stretch of the brook (Site B, $100 \mathrm{~m}$ long by $3 \mathrm{~m}$ wide).

By 2004, both the stilling pond (Site A) and the branch downstream (Site B) were filled with mud 0.5-1.0 m deep. Except for a reed bed near one of the weirs, neither site had any aquatic vegetation. Alder trees (Alnus glutinosa) lined the left bank of the stilling pond and the brook downstream. The right bank of the brook downstream was partially reinforced with submerged brick rubble. The accumulation of silt in Markeaton Brook and its distributory channels was considered to increase the risk of flooding, so de-silting was proposed.

\section{Method}

Work was carried out over a 3-week period in January 2005. The stream was dammed upstream of Site A and pumped into one of the side branches away from Site B. Residual water in the pond was also pumped out. Fish were removed by electrofishing and relocated upstream. During dewatering, two surveyors removed crayfish from the surface of the mud, and searched among tree roots, under dead wood and rubble along a $150-\mathrm{m}$ stretch. Pools of water below the exposed tree roots were sampled with pond nets. No burrows were seen in the banks. A thorough search was made at Site A over a 2-day period, then the mud was excavated and piled on adjacent land surrounded by a bund. No crayfish were found on the excavated mud over the following $48 \mathrm{~h}$. Some crayfish were lost during the pumping of water out of the stilling pond, seven dead crayfish were found downstream of the pump discharge. After de-silting, the pond was allowed to refill. The rescued crayfish were kept in aerated tanks for 3 days and then returned to Site A. 
A similar procedure was followed for the desilting of Site B, which was separated from Site A by a weir and a culvert, with dewatering and fish rescue followed by removal of crayfish along a 100-m stretch, and subsequent excavation (Figure 5). In this case, however, the excavated mud was piled to a depth of $1 \mathrm{~m}$ on the top of the left bank (Figure 6). Three crayfish were found on dredged mud, one being still alive after $24 \mathrm{~h}$ exposure. Crayfish rescued were relocated to Site A, or to a suitable site $1 \mathrm{~km}$ upstream.

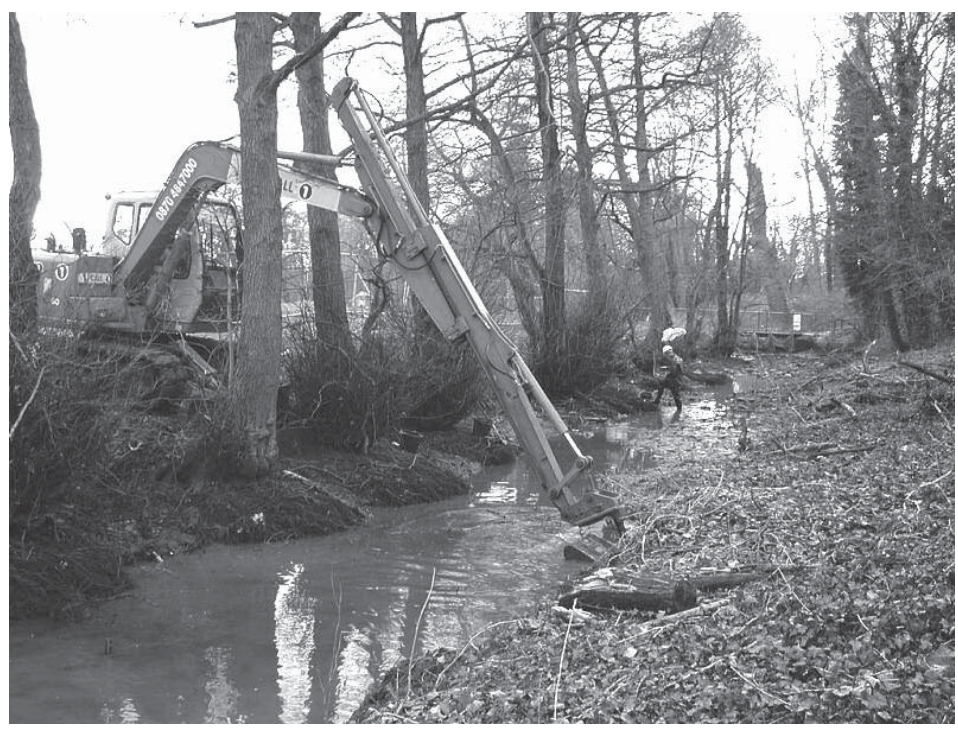

Figure 5

Markeaton Brook, Site B. Removal of mud after partial dewatering. Note exposed tree roots.

Figure 5

Ruisseau Markeaton, Site B. Lessivage de la vase lors d'un assèchement partiel. Remarquez les racines exposées.

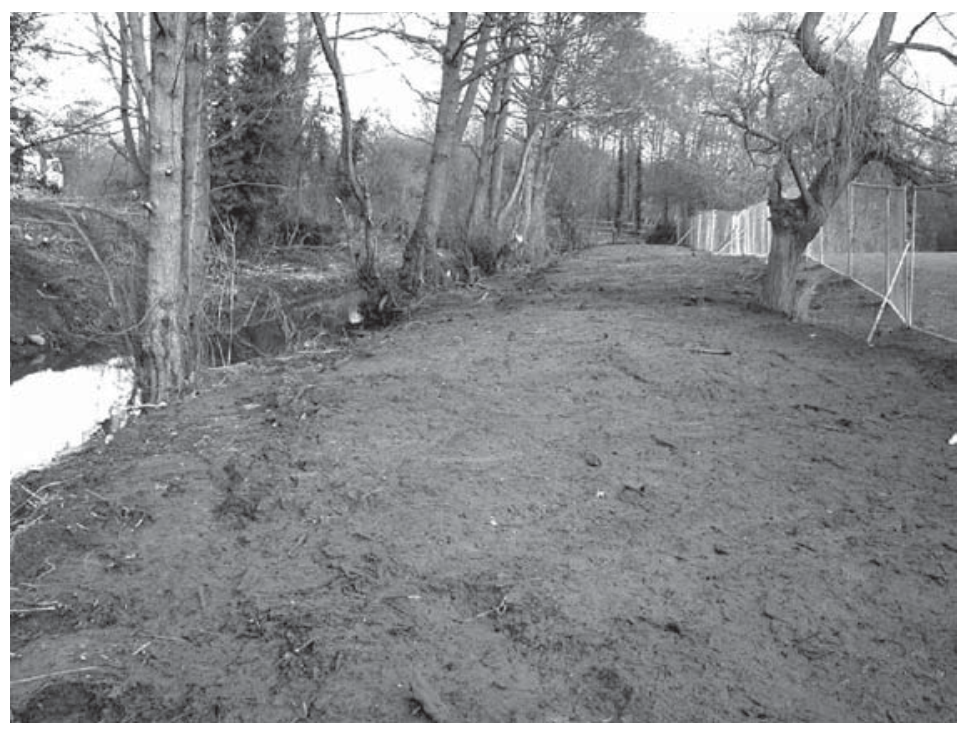

Figure 6

Markeaton Brook, Site B. Substantial quantities of mud deposited on left bank.

Figure 6

Ruisseau Markeaton, Site B. Quantités importantes de vase déposées sur la rive gauche. 


\section{Results}

Fish of 17 species were removed from Sites A and B, some of which are known to be predators of crayfish, including chub (Leucicus cephalus), perch (Perca fluviatilis), pike (Esox lucius) and brown trout (Salmo trutta).

At both Site A and B crayfish were mainly found among alder tree roots (Figure 7), on the surface of the mud (Figure 8), and in pools of water below the exposed roots. Only a small proportion of them were found under the rubble along the right bank of Site B. A total of 141 crayfish was removed from Site A and 292 from Site B. Crayfish were not counted separately by habitat, but the surveyors estimated about $95 \%$ were associated with tree roots along about $250 \mathrm{~m}$ of normally submerged bank, with the remaining $5 \%$ being associated with rubble and mud-covered woody detritus.

\section{Figure 7}

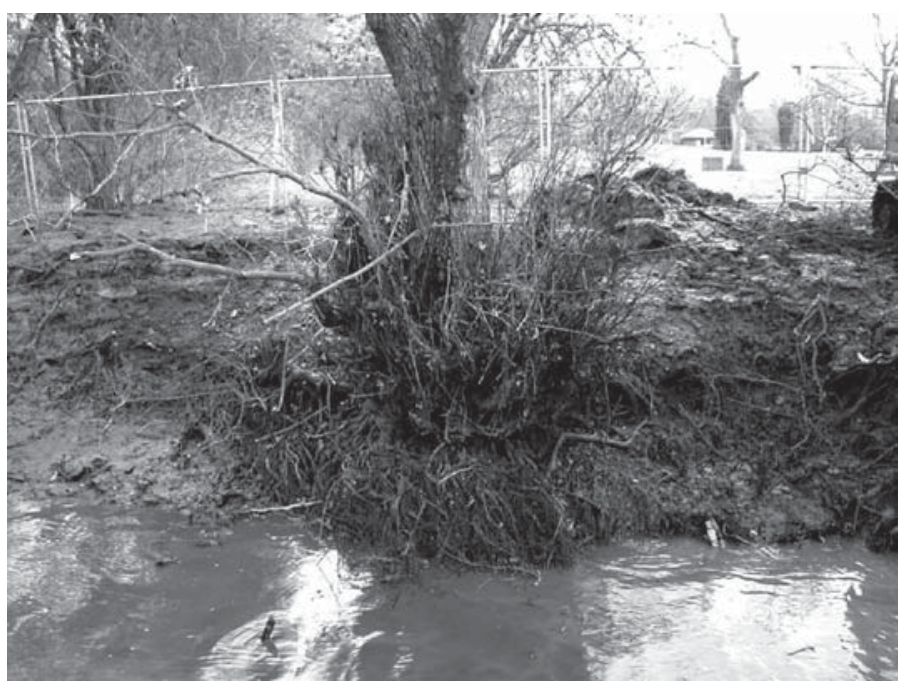

Markeaton Brook, Site B. Tree roots exposed after partial dewatering.

\section{Figure 7}

Ruisseau Markeaton, Site B. Racine d'arbres mises à nu à la suite d'un assèchement.

Figure 8

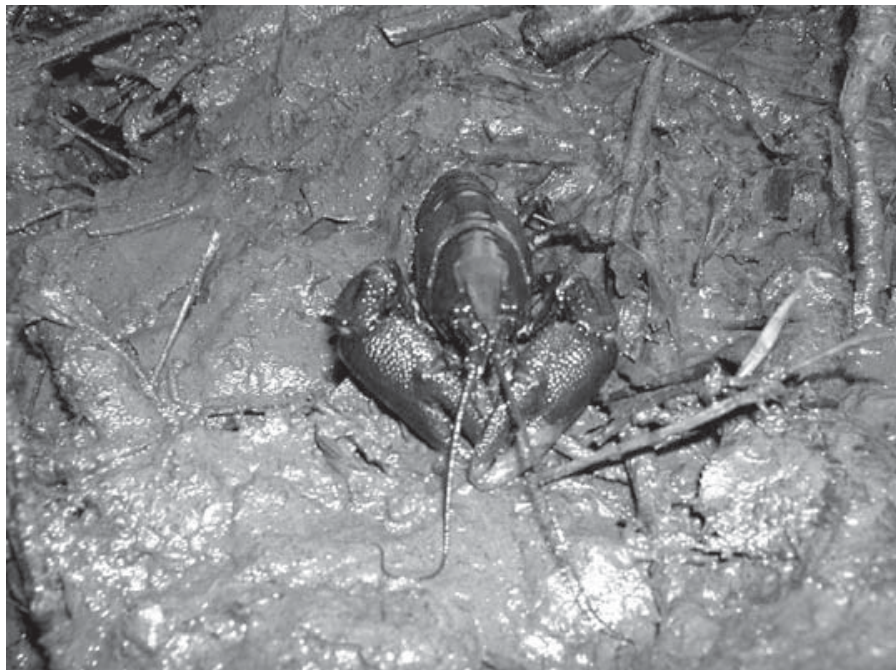

Markeaton Brook, Site B. White-clawed crayfish partially buried in the mud.

\section{Figure 8}

Ruisseau Markeaton, Site B. Écrevisse à pattes blanches partiellement enterrée dans la vase. 
The population structure of the crayfish from Site A is shown in Figure 9. $0+$ individuals that had gone through a number of moults during the previous summer and autumn were relatively common. Most prevalent were individuals in size classes 4 and 5 (19-28.9 mm CL), which probably represent crayfish about 2-3 years old. Older individuals were less frequent. Very few individuals belonging to size class 3 (14-18.9 mm CL) were found (4.25\%). The largest male was $38 \mathrm{~mm} \mathrm{CL}$ and female $34 \mathrm{~mm} \mathrm{CL}$. The smallest female with eggs was $25 \mathrm{~mm} \mathrm{CL}$. Only 14 out of 79 reproductively able females carried eggs, i.e. $17.7 \%$. Egg number varied between approximately 25 and 60 . The male:female ratio was 0.46 . Four percent of individuals were found to have porcelain disease. Only juveniles in the second size class $(9-13.9 \mathrm{~mm})$ were found (18.4\% of total crayfish).

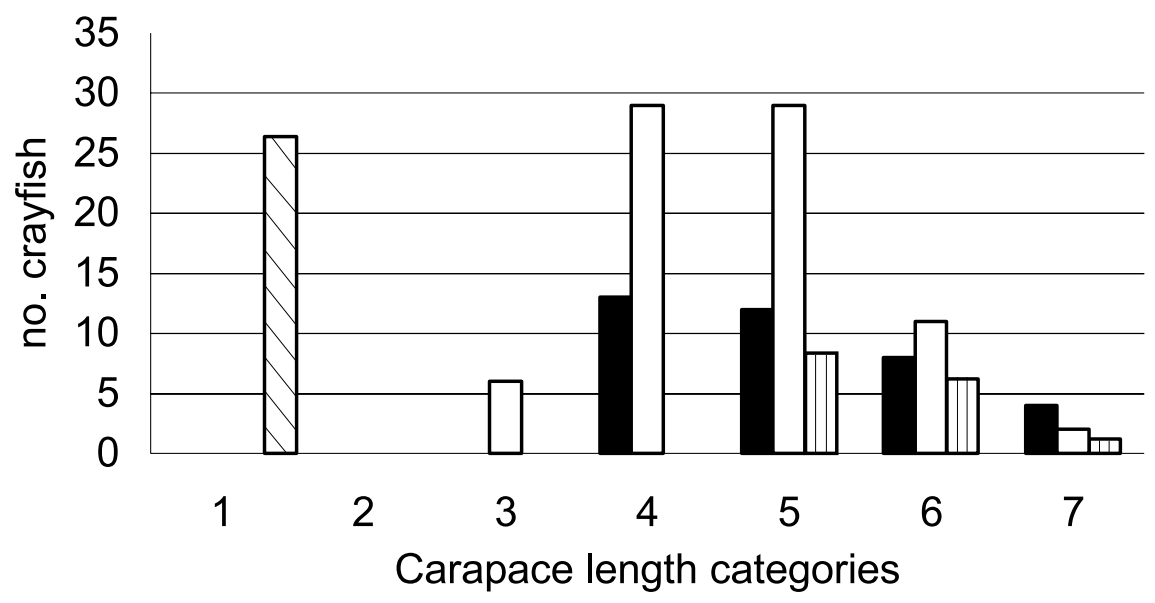

\section{Figure 9}

Markeaton Brook, Site A. Size distribution of juveniles (diagonal stripe), males (black), females (white) and berried females (vertical stripe).

\section{Figure 9}

Ruisseau Markeaton, Site A. Distribution en taille des juvéniles (rayures diagonales), des mâles (noir), des femelles (blanc) et des femelles grainées (rayures verticales).

The population structure of the crayfish from Site $B$ (Figure 10) is much the same as at Site A, although a higher proportion (29.8\% of total crayfish) of juveniles in size class 2 (9-13.9 mm CL) were found. Also, size class 3 (14-18.9 mm CL) was missing from the samples. Some large males and females were present, probably over 6 years old. The largest male was $45 \mathrm{~mm} \mathrm{CL}$ and the largest female was $48 \mathrm{~mm} \mathrm{CL}$. Of the mature females 34\% were found to be carrying eggs. Egg number varied between 30 and 100 . The smallest female with eggs was only $23 \mathrm{~mm}$ CL. The male:female ratio was 0.90 . Only $2.4 \%$ of crayfish were found to have porcelain disease, although one $0+$ individual was found to be infected.

\section{Discussion}

Both areas had healthy populations of crayfish with a relatively low incidence of porcelain disease. An unusual feature is the low percentage of females carrying eggs. Low recruitment of juveniles is expected next year, although last year's recruitment 


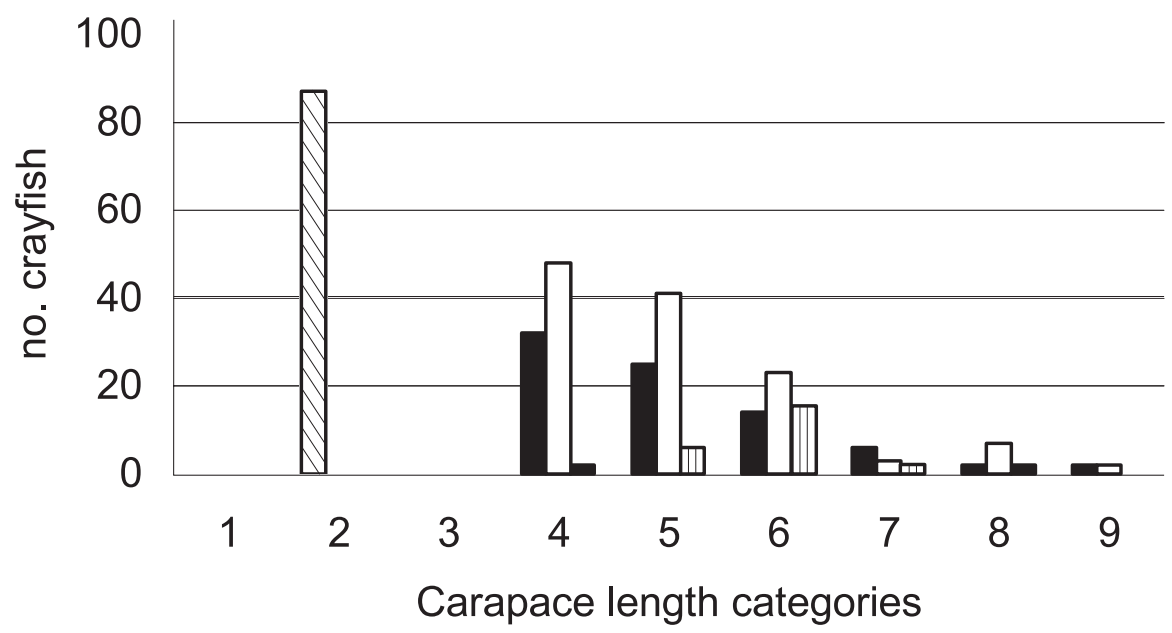

Figure 10

Markeaton Brook, Site B. Size distribution of juveniles (diagonal stripe), males (black), females (white) and berried females (vertical stripe).

\section{Figure 10}

Ruisseau Markeaton, Site B. Distribution en taille des juvéniles (rayures diagonales), des mâles (noir), des femelles (blanc) et des femelles grainées (rayures verticales).

(2004) appears to have been good. The fact that only size class 2 (9.0-13.9 mm CL) juveniles were recorded indicates that size class 1 (4.0-8.9 $\mathrm{mm} \mathrm{CL})$ juveniles moulted before the onset of winter. Recruitment in 2003 may have been poor, as size class 3 is missing for that year from Site B and only low numbers were recorded at site $A$. The reason for this is not known. Although summer 2003 was particularly hot and dry, the impoundment of the stream by weirs meant that the water level was maintained and it appears that the alder roots would have remained covered, even during low flows. The low number of females carrying eggs may be due to a number of factors, including environmental stress caused by limited habitat and consequent overcrowding. A female of $23 \mathrm{~mm} \mathrm{CL}$. was found to be carrying eggs, which equals the smallest size recorded by RHODES and HOLDICH (1982), and is only just above the minimum breeding size of $22 \mathrm{~mm}$ recorded by PEAY (2002).

The mud at both sites was relatively deep and reached up into the alder tree roots hanging into the water. The fact that the majority of crayfish were found associated with alder tree roots highlights the importance of this type of refuge, for both juveniles and adults. Conventionally, when crayfish are associated with tree roots it is in clean rivers where the roots hang in loose wads in open water (e.g. SMITH et al., 1996). By contrast, at these sites, whilst there were places with roots in water, crayfish were also seen amongst roots almost entirely buried in mud. The roots of all the trees were left intact, which should allow crayfish the opportunity to recolonise. In theory, the removal of the mud should improve the habitat for the crayfish. 


\section{Darnford Brook (S. PEAY)}

\section{Site description}

Darnford Brook (Figure 11) is a tributary of the River Thame near Lichfield (central England) (OS grid reference: SK 193 095), which runs through pasture, with trees, mainly alder, Alnus glutinosa, and crack willow, Salix fragilis, on one side, with a bed mainly of sand and gravel. Where willows have fallen, partly damming the stream there are pools full of twigs and mud. In August 2000, a few white-clawed crayfish (10) were found by manual searching among brick rubble under a small bridge and under overhanging turf in a shallow section. The stream passes under a railway line in a culvert and engineering works necessitated installation of a temporary haul road across the stream. Temporary dewatering was required to install a $5 \mathrm{~m}$ wide crossing.

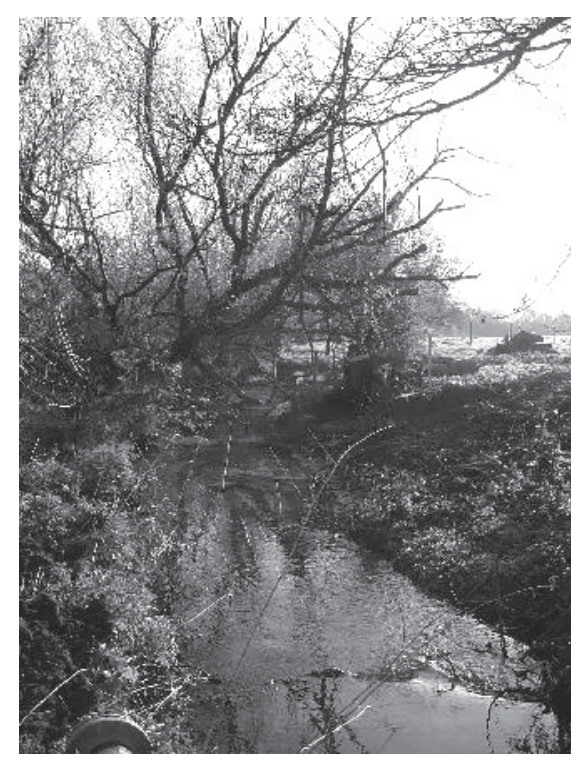

\section{Figure 11}

\section{Darnford Brook. General view.}

\section{Figure 11}

Ruisseau Darnford. Vue générale.

The site directly affected consisted of a pool upstream of a fallen willow, with a steep submerged bank $10 \mathrm{~m}$ along one side. A few fine tree-roots were present along the edge of one bank, but were frequently exposed by natural variation in water level and hence were not expected to be very favourable habitat for crayfish. The pool was up to $2 \mathrm{~m}$ wide and approximately $0.6 \mathrm{~m}$ deep. Upstream of the pool the substrate was very silty, with soft, black mud infilling the channel to a shallow V-shape about $1.2 \mathrm{~m}$ wide. Some water forget-me-not, Myosotis scorpioides, was growing on the muddy margins at the upstream end, but there was no other aquatic vegetation.

\section{Methods}

Dewatering was carried out on $22^{\text {nd }}$ April 2005. Small dams made of sandbags and polythene sheeting were installed upstream and downstream of the haul road crossing. A pump was used to divert the flow from the working area. Another pump was used to dewater the pool immediately downstream of the area required for the culvert. 
As the water level fell crayfish burrows were exposed along about $6 \mathrm{~m}$ of the left bank, below the level of the few tree roots. The first white-clawed crayfish was seen emerging from a burrow (Figure 12) about 10-15 minutes after dewatering and many others soon appeared from burrows, woody detritus and from beneath the surface of the mud and were collected by hand by a crayfish surveyor and construction staff. Most crayfish emerged within the first hour. The banks and bed were excavated along the $5 \mathrm{~m}$ length required to accommodate the new culvert. Excavated material was spread 0.3$0.5 \mathrm{~m}$ deep on one bank and inspected for any further crayfish. In the pool, which was dewatered but not excavated, some crayfish continued to emerge up to 3 hours from the start of dewatering.

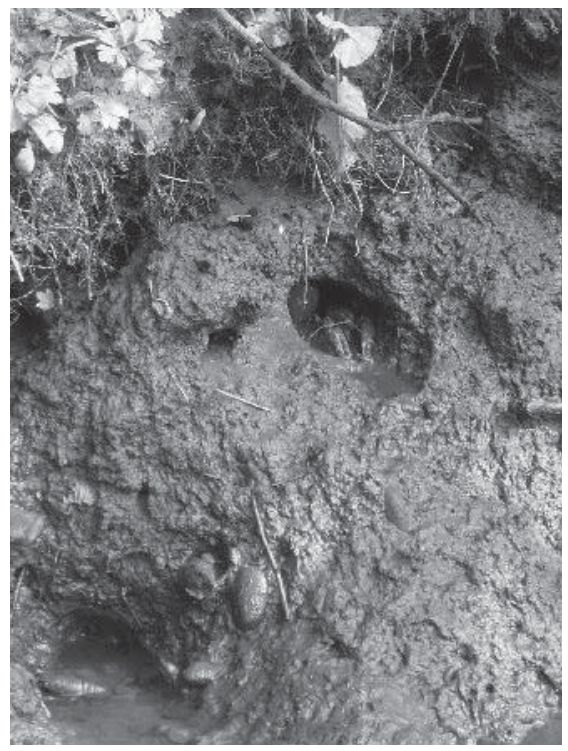

\section{Figure 12}

Darnford Brook. White-clawed crayfish in burrows in the mud.

\section{Figure 12}

Ruisseau Darnford. Écrevisse à pattes blanches dans des terriers creusés dans la vase.

The size, sex and condition of crayfish removed from the channel were recorded. They were moved to a site downstream and released among tree roots and next to steep submerged banks. Bricks with holes were set out in the area upstream and downstream of the new culvert, to facilitate monitoring and provide some replacement refuges.

\section{Results}

A total of 202 crayfish was removed from the $10 \mathrm{~m}$ section of stream, an area of around $12-18 \mathrm{~m}^{2}$, and their size distribution is shown in Figure 14. Most crayfish (123) emerged in the first hour and the number declined over the next 2 hours. There was a slight bias toward males, $46 \%$ male, $40 \%$ female and the remaining $14 \%$ were juveniles of unidentified sex, all in size classes 1 and 2 (7-11 mm CL). As the work was carried out in late April, there were berried females present, $31 \%$ of the total females. Only $27 \%$ of those below $30 \mathrm{~mm}$ CL carried eggs, compared to over $60 \%$ of those above $30 \mathrm{~mm}$ CL. 
The distribution of crayfish was uneven. Detailed subdivision by habitat was not possible, but nearly half the total came from a pile of small twigs (Figure 13), decomposed leaf litter and black silty mud in the pool, an area approximately $1-1.5 \mathrm{~m}^{2}$. By contrast, a sloping bank of bare sand had only two crayfish. There was little urban detritus in the stream, but a discarded drinks can held two crayfish. No crayfish were seen in the excavated spoil, although it is possible that a few were buried and unable to dig their way out that day.

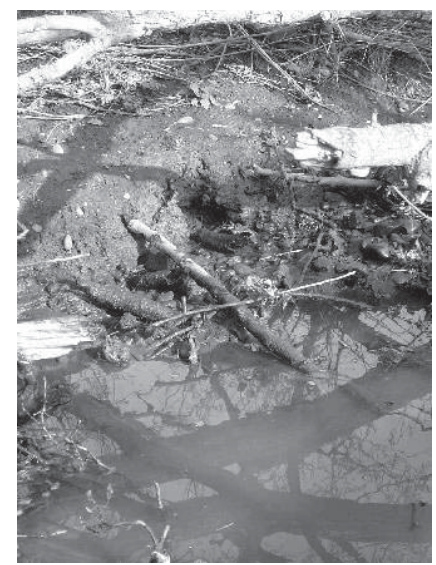

\section{Figure 13}

Darnford Brook. Piles of twigs that were utilized by the crayfish.

\section{Figure 13}

Ruisseau Darnford. Piles de brindilles qui ont été utilisées par les écrevisses.

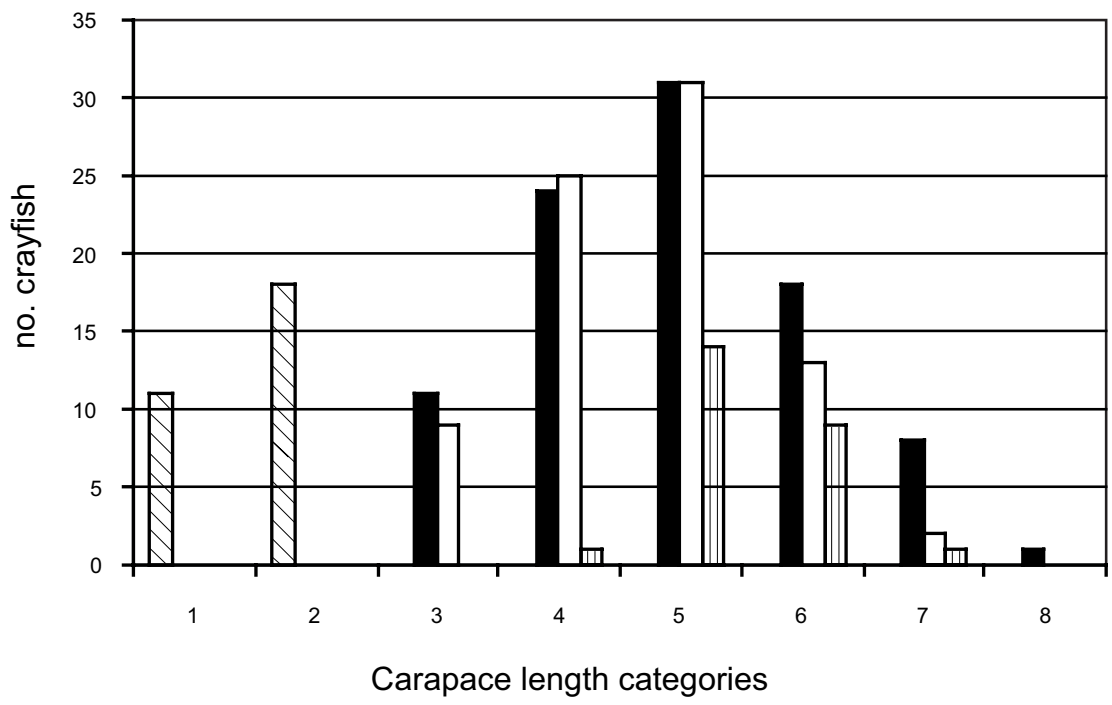

Figure 14

Darnford Brook - size distribution of juveniles (diagonal stripe), males (black), females (white) and berried females (vertical stripe).

\section{Figure 14}

Ruisseau Darnford. Distribution en taille des juvéniles (rayures diagonales), des mâles (noir), des femelles (blanc) et des femelles grainées (rayures verticales). 


\section{Discussion}

The overall density was found to be approximately 11-16 crayfish $\mathrm{m}^{-2}$, high for a section of stream that would probably be rated as poor habitat, with only localised areas of moderate quality. The small pile of twigs and organic silt was by far the most favourable area for crayfish, with a density at least 50 crayfish $\mathrm{m}^{-2}$. A similar muddy pile of twigs immediately downstream of the upper dam also had a lot of crayfish. Burrows were localised, but where present, there were about 10 burrows $\mathrm{m}^{-1}$ of submerged bank. At this site there was little extension of tree-roots into the water and crayfish were not found among the few roots that were present, probably because most of them were exposed to air, except during high flows.

The number of crayfish in the mud and woody detritus was under-estimated, because crayfish were still emerging sporadically from this area when the attention of the team was concentrated on the excavation of the channel. Some crayfish were seen walking down into the water that remained at the bottom of the pool and not all of them were retrieved. Some may have been lost through the pump intake, but others submerged themselves in the mud and were left, as this area was not excavated.

Crayfish showed some reluctance to emerge when there was a lot of human activity in the channel. The best catches of crayfish from the woody detritus were obtained by waiting on the bank for a few minutes, collecting as many crayfish as possible from the channel, returning to the bank and waiting again. Whilst some juveniles were caught, they tended to be missed by the construction staff and the juvenile population is certainly under-recorded. It is interesting that size class 1 juveniles $(4.0-8.9 \mathrm{~mm} \mathrm{CL})$ were recorded in late April, in contrast to the sites at Markeaton Brook, where none were recorded.

The small woody debris may have improved the structure of the mud, making it easier for crayfish to penetrate along the mesh of twigs, improving stability of the mud during variable flows and possibly allowing better access of oxygenated water into the refuges of crayfish. Nonetheless, some crayfish were seen emerging vertically, chelae first, from beneath the surface of mud, with no sign of any burrow entrance visible at the surface.

\section{Huddersfield Narrow Canal (J. H. BRICKLAND)}

\section{Site description}

The Huddersfield Narrow Canal, in West Yorkshire (northern England) (OS grid reference: SE 104 155), is a totally artificial structure. It was constructed from puddled clay at least $60 \mathrm{~cm}$ thick, the banks were then lined with stone or wooden piling and sometimes planted with rushes, Juncus spp., to protect the clay and prevent it from drying out. The canal was opened in 1811, but from 1944 it was abandoned. A 4-year restoration programme was started in 1997, which included replacement of a swing bridge. This necessitated dewatering (a draw-down) of a section of the canal, an operation that is carried out periodically by British Waterways to allow inspections, engineering work and de-silting. There were records of white-clawed crayfish from the canal, so a crayfish rescue was required.

The walls of the canal at this site were constructed from laid stone with no mortar on the towpath side (Figure 15). The other bank of the canal had a submerged, unmortared stone wall around the base of a bridge, but the rest of that bank was soft earth and partially covered in vegetation. The bed was a continuous layer of mud, which had accumulated over decades, together with some scattered urban debris (bottles, cans, wheels etc.). 


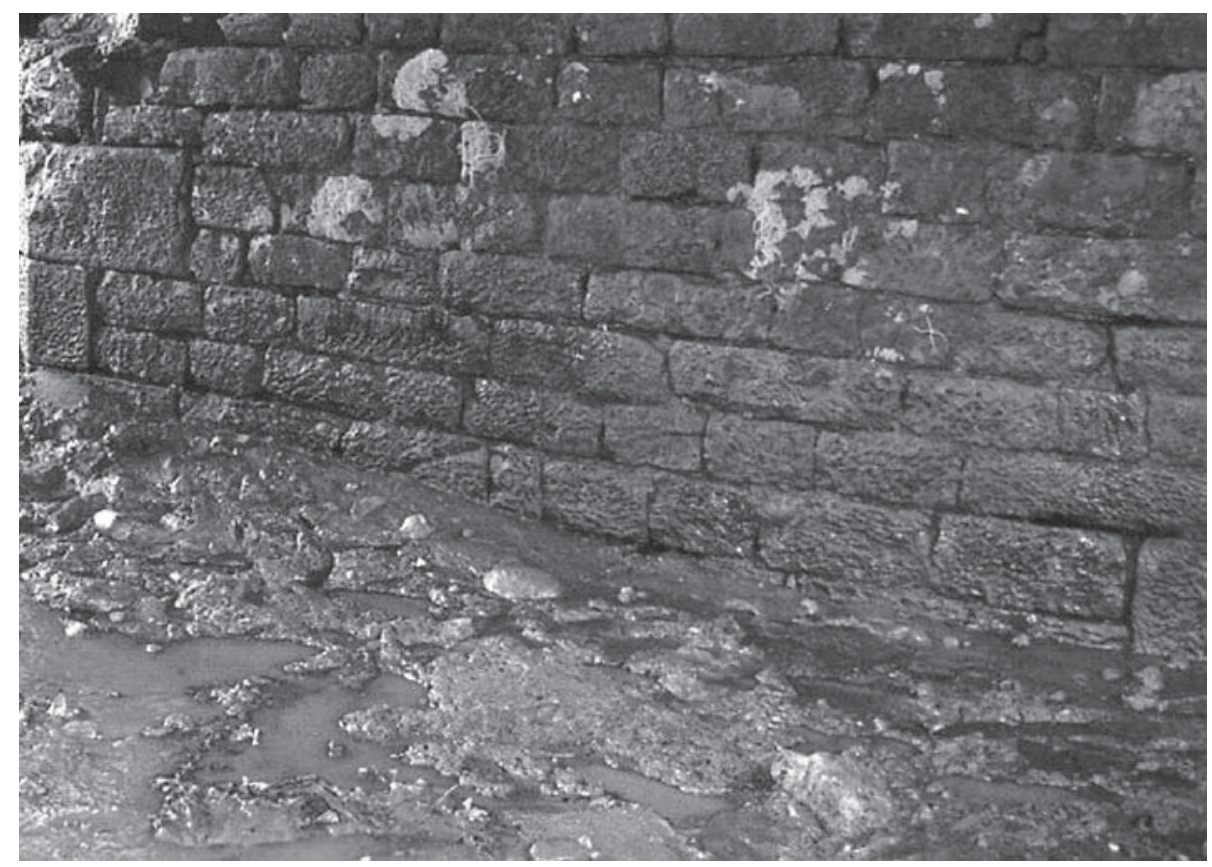

\section{Figure 15}

Huddersfield Narrow Canal. Showing unmortared wall that provides refuges for the crayfish.

\section{Figure 15}

Huddersfield Narrow Canal. Montrant le mur sans mortier qui fournit des refuges pour les écrevisses.

\section{Methods}

A capture, mark recapture exercise was carried out on the canal section in October 1999 (SILVER, 2000). Over six nights, crayfish traps were set in the canal and retrieved each day. Traps were baited with smoked mackerel. For the first two nights 10 traps were used, for the next four nights 30 traps were used. Crayfish were marked and the carapace length and sex was noted, other data recorded included whether females were berried. All animals were returned to the section. Some observations of crayfish were also made from the towpath by torchlight at night at several sites on the canal. Another trapping session was carried out before the start of engineering work in November, when a 20-m section of the canal was isolated using temporary barriers or bunds.

Pumps were used to take the water out of this section of canal and as the water level dropped crayfish emerging from the gaps in the stonewall were captured by a team of people using hand nets. Crayfish were recorded and released into the canal outside the de-watered area. Over-night the canal was allowed to refill with water, and a second drawdown was carried out, accompanied by a second crayfish rescue. A third draw-down and rescue was also undertaken. After the rescues and during the engineering works, further crayfish were found, these were retained and then measured. Crayfish were not observed emerging from refuges in the soft earth banking and consequently efforts to catch them were focussed on the walled areas. 


\section{Results}

The capture, mark recapture exercise caught 48 crayfish, only nine of these were subsequently recovered during the draw down. The average number of crayfish per trap night (CPUE) was 0.4. The adult male: female ratio was 0.78 . The maximum populations estimated using the Peterson Method and Baileys Triple Catch Method were 168 and 66 respectively. With one exception (a male $19 \mathrm{~mm}$ ), the minimum size of crayfish in traps was $30 \mathrm{~mm}$. The trapping undertaken immediately prior to the draw-down caught 13 crayfish, all males with an average carapace length of $40 \mathrm{~mm}$ (range 31-47 mm). Turbidity prevented night-viewing at the site of the swingbridge, but 28 crayfish were seen in a clearer section upstream.

The catches of crayfish during the three draw-downs were 190, 176 and 60, with a further 110 caught subsequently during the works. In all 549 crayfish were removed from the $20 \mathrm{~m}$ length of canal. The population structure is shown in Figure 16. All crayfish with a carapace length of less than $14.0 \mathrm{~mm}$ were recorded as juveniles. Although the majority of juveniles were in size class 2 (9.0-13.9 mm CL) (109 no.), some were smaller (7 no.). Together, these juvenile size classes represented $21 \%$ of the total catch. A total of 193 males were caught with an average carapace length of $29.5 \mathrm{~mm}$ (range 14.0-48.3 mm). A total of 225 females were caught with an average carapace length of $28.7 \mathrm{~mm}$ (range 14.0-46.1 mm). The smallest berried female had a carapace length of $26 \mathrm{~mm}$. Of 141 females with a carapace length of $26 \mathrm{~mm}$ or greater; $111(78.7 \%)$ were berried. The total number of crayfish in size classes 6 and above $(29 \mathrm{~mm} \mathrm{CL}$ or above, i.e. approximately the range recorded in traps) was 223 , or $40 \%$ of the total rescued. Of these only 9 (4\%) were previously marked from trapping.

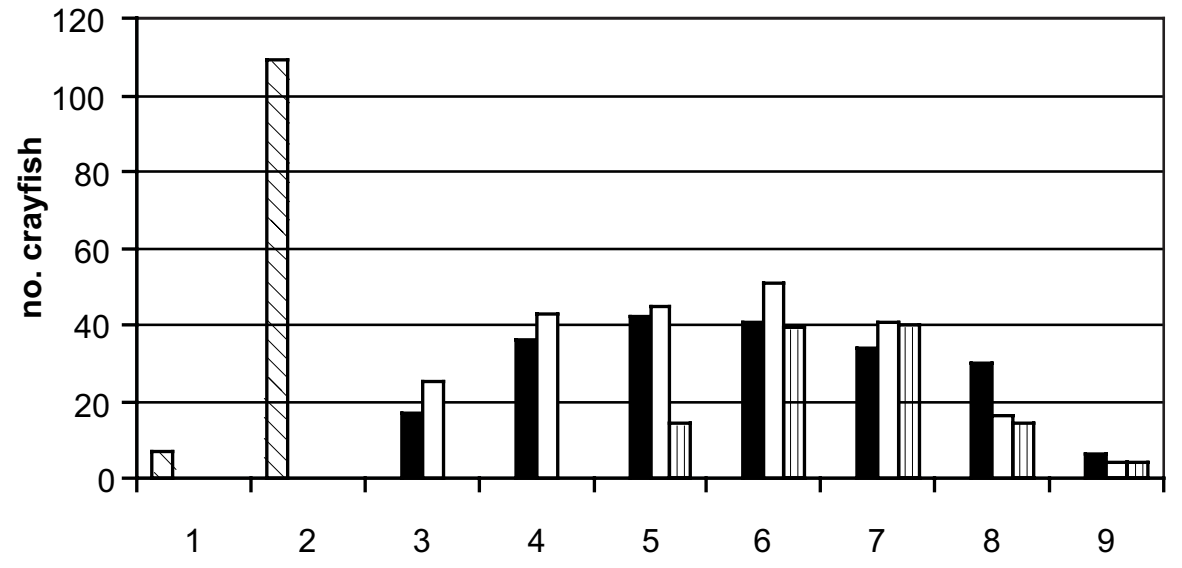

Carapace length categories

\section{Figure 16}

Huddersfield Narrow Canal. Size distribution of juveniles (diagonal stripe), males (black), females (white) and berried females (vertical stripe).

\section{Figure 16}

Huddersfield Narrow Canal. Distribution en taille des juvéniles (rayures diagonales), des mâles (noir), des femelles (blanc) et des femelles grainées (rayures verticales). 
In terms of habitat there was a total of $20 \mathrm{~m}$ of dry laid stonewall on one side of the canal and approximately $10 \mathrm{~m}$ around the base of the bridge, this would be submerged under $1 \mathrm{~m}$ of water, creating a total available habitat of $30 \mathrm{~m}^{2}$. If the crayfish were solely occupying refuges in the walls, a total of 549 crayfish represents a minimum density of 18 crayfish $\mathrm{m}^{-2}$

\section{Discussion}

Collecting by hand during draw-downs is one of the best methods for rescuing crayfish, primarily because of the inefficiency or unsuitability of other methods such as trapping and night searching. The estimate of population size by mark recapture was poor, even allowing for the size selectivity. However, results in this case study suggest that even collecting during a series of draw-downs may not be as efficient as had been thought. The capture, mark recapture exercise, one month prior to the engineering works, released 48 marked crayfish into this section. The fact that only nine of these were recovered during the series of draw-downs and the engineering works suggested that many crayfish remained uncaught. It is also possible that some crayfish moved out of the site prior to installation of the bunds. The very fact that crayfish were caught in traps is a positive indication that they use the muddy canal bed for foraging for food.

Most adults tended to emerge during the first and second draw-downs. The data suggests that juveniles were reluctant to emerge. It is believed that crayfish may opt not to emerge in an attempt to avoid predation, as emerging would be a risky option in daylight. Remaining in the refuge could also be risky if water levels did not rise again quickly. Repeating the draw-down several times may "persuade" crayfish to emerge. Juveniles may be at greater risk from predation than adults since the adults themselves are potential predators - this may explain their apparent "reluctance" to emerge during the draw-down. An alternative explanation could be that they are difficult to catch by hand and with nets, especially in muddy conditions. Large animals are more easily seen and caught. Some crayfish managed to crawl out of reach of the nets into muddy pools in the bottom of the canal in areas too soft for access. They probably accounted for at least part of the $20 \%$ of crayfish found in the fully drained canal after the start of engineering work. Some were found in muddy urban debris during dewatering.

The results demonstrate that the canal provides a good habitat for the white-clawed crayfish, despite its muddy bed. Crayfish require suitable refuges and also a food supply and foraging area. The gaps in the stonework clearly provide an ideal refuge. Crayfish have been seen out on the deep anoxic mud at night (SILVER, 2000), which seems to confirm that the canal bed is used for foraging, and plays a key role in supporting a good population of white-clawed crayfish.

\section{DISCUSSION}

HOBBS and HALL (1975) state that siltation has an adverse impact on crayfish habitat, and that under conditions of heavy siltation they are rarely found, although they may tolerate high levels of suspended sediment. FOSTER (1995) gives a range of 7.5$33.6 \mathrm{mg} \mathrm{l}^{-1}$ suspended solids for the white-clawed crayfish. It is rare to find any mention in the literature of white-clawed crayfish actually living in muddy habitats, although other people the authors have contacted have unpublished observations. MACHINO and FÜREDER (1996) mention that the white-clawed crayfish is known as the "swamp crayfish" in Carinthia. People from the Gitschal region were apparently of the opinion that the white-clawed crayfish preferred swampy areas to normal streams. HOLDICH and ROGERS (2000) describe a brook in which the substratum was composed entirely of sand and silt, with annual vegetation overhanging the banks. No crayfish were found during a hand and net survey, but 400 were caught in traps over a $100-\mathrm{m}$ section. The 
crayfish were living in burrows. Similarly, burrowing behaviour of white-clawed crayfish has been rarely mentioned in the literature (PEAY and HIRST, 2003; TERO et al., 2003) since the observations of HUXLEY (1881), but has been confirmed by other studies (P.D. Hiley, unpublished observations in the River Wye, Wales and its tributaries, 1955-1958; R. Colne, R. Lambourne and tributaries, 1970-1974; R. Wharfe, R. Ure and Semerwater, 1976-1978). White-clawed crayfish are also known to burrow in riverbanks in mainland Europe, e.g. in Spain (F. Alonso, 2005, pers. comm.).

Crayfish living in muddy habitats may use tree roots, marginal vegetation, heaps of twigs, debris, and crevices in brickwork as refuges, and they probably obtain a proportion of their food from trapped debris there, but it appears they also forage onto the mud surface to obtain additional food, as observed during night viewing (R. Derwent, Huddersfield Narrow Canal). Recent night observations (Sept. 2005) on a muddy pool in the Japanese Water Gardens at Newstead Abby (Nottinghamshire) by one of us $(\mathrm{DMH})$, found white-clawed crayfish emerging from the banks one hour after sunset, and foraging about on the surface of the mud in $6 \mathrm{~cm}$ of water. Mud that has a high content of organic silt provides a rich source of macroinvertebrates, particularly tubificid worms and chironomid larvae, as well as detritus and decaying foliage from overhead vegetation. In the Darnford Brook, areas of mud with a high sand content and little organic matter had very few crayfish, whereas mud with a high content of organic silt supported abundant crayfish, although only where fine twigs were present, which probably stabilise the mud. Due to their low centre of gravity crayfish are able to support themselves and walk on the mud surface. Although white-clawed crayfish are known to occupy burrows, the Darnford study shows they can also use refuges beneath the surface of mud with small woody detritus, but no visible burrow entrance.

Crayfish are known to be able to tolerate low oxygen conditions as might be found on the mud surface, and short-term hypoxia as might be found within the mud (McMAHON, 2002). However, in many situations white-clawed crayfish have been found apparently living in the mud, so they must be able to tolerate very low oxygen concentrations over longer periods and, as shown by McMAHON (2002), they have physiological compensatory mechanisms for doing this. Therefore the main problem for them should be maintaining a flow of water over their gills. The entrances to the gill cavity are guarded by filters of setae at the base of each leg (VOGT, 2002), but these may become clogged where there is a fine layer of flocculant layer on the surface of the mud (detached aufwuch) and is the main reason given for crayfish not occupying muddy habitats. However, crayfish are known to be able to reverse the current through the gill chamber to unclog the filters. This mechanism may be used by white-clawed crayfish living in muddy habitats. In addition, limb movement activates various structures within the gill chamber that clean the gills (VOGT, 2002).

It has been shown in this paper that dewatering can be a useful method for examining crayfish habitat. It enables a much larger number of crayfish to be sampled than with conventional survey methods. It is much less biased towards the larger size classes than trapping and provides size distributions that are either comparable with those from manual surveys, or better. Muddy habitats are seldom suitable for manual surveys whilst covered by water, and although juvenile crayfish can be netted from tree roots, the authors have found that the yields are very low. If site conditions are suitable and time is available during the works, a higher proportion of the juvenile population can be obtained, as at Site B on Markeaton Brook and the Huddersfield Narrow Canal, although even in those cases the juveniles were probably still underestimated.

As suitable refuges can be very limited in muddy conditions, it is very important during desilting operations that refuges such as trees roots hanging down into the water and banks suitable for refuges are retained. Whilst some works can cause loss of refuges, de-silting may make new areas accessible to crayfish. 
In the UK, crayfish ecologists are often asked to assess whether a watercourse is likely to support the white-clawed crayfish and hence whether mitigation measures for this protected species are required during engineering works (PEAY, 2000; HOLDICH et al., 2004). Based on published literature the impression obtained is that in a waterbody full of deep, anoxic sediment white-clawed crayfish would be absent, or present only at very low abundance. This paper has shown that white-clawed crayfish do occupy habitats with such conditions and in relatively large numbers. Such habitats need to be considered when carrying out crayfish surveys and planning essential maintenance work.

\section{ACKNOWLEDGEMENTS}

David Holdich thanks the staff of EMEC Ecology for assisting with the collection and measurement of the crayfish from Markeaton Brook; Derby City Council for providing funding and advice, as well as permission to publish the data; and Jon Wall and his team for undertaking the electrofishing survey. John Foster thanks The World Wide Fund for Nature (WWFN) for financial support and Mr Delaney for permission to survey the Mortimer's Cross site. Stephanie Peay and Peter Hiley thank Yorkshire Water for permission to publish the R. Derwent study; Barry Barton, Will McBain, Mark Fletcher and James Lancaster from project engineers RKL ARUP, and others who helped with nightviewing, including Sue Loveridge, Phil Eades, Paul Bradley, Laura Smith and Jill Wright. Stephanie Peay thanks Jim Pearson of Network Rail for permission to publish data from the Darnford Brook project; Mick Rowe, Network Rail for his assistance on site, together with site manager Julian Wilson and all the site staff who participated in the project. Jonathan Brickland thanks British Waterways for permission to publish; Stuart Silver for the crayfish survey, and those additional persons who worked on the crayfish rescue and relocation of the crayfish, particularly Nick Birkinshaw, Stephanie Peay and Alice Hiley.

\section{REFERENCES}

BRICKLAND J., SILVER S., LEACH J., 2006. Crayfish distribution in the waterway network of Britain and issues for British Waterways. Freshwater Crayfish, 15, 11 p.

BROWN D.J., BREWIS J.M., 1979. A critical look at trapping as a method of sampling a population of Austropotamobius pallipes in a mark and recapture experiment. Freshwater Crayfish, 4, 159-163.

DEMERSA., REYNOLDSJ.D.,2002. A survey of the white-clawed crayfish, Austropotamobius pallipes (Lereboullet) and of water quality in two catchments of Eastern Ireland. Bull Fr. Pêche Piscic., 367, 729-740.

FOSTER J., 1995. Factors influencing the distribution and abundance of the crayfish Austropotamobius pallipes (Lereboullet) in Wales and the Marches, UK. Freshwater Crayfish, 8, 78-98.

FOSTER J., 1996. Distribution and abundance of the native crayfish Austropotamobius pallipes (Lereboullet) in Wales and the Marches, UK. Unpublished PhD thesis, University of Wales, Cardiff (UWCC), Cardiff, Wales.

GRANDJEAN F., MOMON J., BRAMARD M., 2003. Biological water quality assessment of the white-clawed crayfish habitat based on macroinvertebrate communities: usefulness for its conservation. Bull. Fr. Pêche Piscic., 370-371, 115-125.

HOBBS H.H. Jr., HALL E.T., 1975. Crayfishes (Decapoda: Astacidae). In: Pollution ecology of freshwater invertebrates. HART C.W., FULLER S.L.H. (Eds.), 195-214, Academic Press, New York and London. 
HOGGER J.B., 1988. Ecology, population biology and behaviour. In: Freshwater crayfish: biology, management and exploitation. HOLDICH D.M., LOWERY R.S. (Eds), 114144, Croom Helm, London.

HOLDICH D.M., 2003. Ecology of the white-clawed crayfish. Conserving Natura 2000 Rivers, Ecology Series No. 1. English Nature, Peterborough: 17 p.

HOLDICH D.M., ROGERS D., 2000. Habitat requirements of the white-clawed crayfish, Austropotamobius pallipes. In: Crayfish Conference Leeds. ROGERSD., BRICKLAND J. (Eds), 109-121, Environment Agency, Leeds.

HOLDICH D.M., SIBLEY P., PEAY S., 2004. The white-clawed crayfish - a decade on. British Wildlife, 15, 153-164.

HUXLEY T. H., 1881. The crayfish. An introduction to the study of zoology. $3^{\text {rd }}$ ed. Keegan Paul, London.

LOWERY, R.S., HOGGER, J.B., 1986. The effects of river engineering works and disease on a population of Austropotamobius pallipes in the River lea, UK. Freshwater Crayfish, 6, 94-99.

MACHINO Y., FÜREDER L., 1996. Der Kärtner "Sumpfkrebs" im Gailtal. Österreichs Fischerei, 49 (4), 93-97.

McMAHON B.R., 2002. Physiological adaptation to environment. In: Biology of freshwater crayfish. HOLDICH D.M. (Ed.), 327-376, Blackwell Science, Oxford.

NAURA M., ROBINSON M., 1998. Principles of using river habitat survey to predict aquatic species, an example applied to the white-clawed crayfish Austropotamobius pallipes. Aquatic Conservation, 8, 515-527.

PEAY S., 2000. Guidance on works affecting white-clawed crayfish. Report for English Nature. Contract FIN/CON/139, $27 \mathrm{p}$.

PEAY S., 2002. A monitoring protocol for the white-clawed crayfish. Field-testing in River Eden tributaries, summer 2002. English Nature, Peterborough: 57 p.

PEAY S., 2003. Minimising loss of crayfish and habitat during works on watercourses. Bull. Fr. Pêche Piscic., 370-371, 193-208.

PEAY S., 2004. A cost-led evaluation of survey methods and monitoring for white-clawed crayfish. Lessons from the UK. Bull. Fr. Pêche Piscic., 372-373, 335-352.

PEAY S., HIRST D., 2003. A monitoring protocol for white-clawed crayfish in the UK. In: Management and conservation of crayfish. HOLDICH D.M., SIBLEY P.J. (Eds), 3955, Proceedings of a conference held on $7^{\text {th }}$ November 2002, Environment Agency, Bristol.

PEAY S., HILEY P.D., COLLEN P., MARTIN I., 2006. Biocide treatment of ponds in Scotland to eradicate signal crayfish. Craynet Volume 4, Bull. Fr. Pêche Piscic., 380-381, 1363-1370.

RICKER W.E., 1975. Computation and interpretation of biological statistics of fish populations. Bulletin of the Fisheries Board of Canada, 191, 1-382.

RHODES C.P., HOLDICH D.M., 1982. Observations on the fecundity of the freshwater crayfish, Austropotamobius pallipes (Lereboullet) in the British Isles. Hydrobiologia, 89, 231-236.

SILVER S., 2000. A study of the Huddersfield Narrow Canal, and its habitat suitability for the native white-clawed crayfish, an analysis of ecological census techniques in a deep-water environment. Unpublished BSc (Hons) Geography dissertation, Division of Geographical and Environment Sciences, University of Huddersfield: 66 p. 
SMITH G.R.T., LEARNER, M.A., SLATER F.M. and FOSTER J., 1996. Habitat features important for the conservation of the native crayfish Austropotamobius pallipes in Britain. Biological Conservation, 75, 239-246.

TERO C., HOLDICH D.M., SMITH P., KITE N., LONGFIELD R., SMITH P., 2003. Whiteclawed crayfish, Austropotamobius pallipes, in the River Witham, Lincolnshire. HOLDICH D.M., SIBLEY P.J. (Eds), 159-168, Proceedings of a conference held on $7^{\text {th }}$ November 2002, Environment Agency, Bristol.

VOGT G., 2002. Functional anatomy. In: Biology of freshwater crayfish. HOLDICH D.M. (Ed.), 53-151, Blackwell Science, Oxford. 